\title{
Brave New Digital World? - Financial Technology and the Power of Information*
}

\author{
Ádám Kerényi - János Müller
}

In this paper we focus on the development of FinTech, how is it evaluated and managed in selected areas, in the European Union, in China and in Hungary. Some of the pertinent questions in this field are the following: How can regulators keep up with the rapid pace of development? Can regulation be based on a precise definition and can a level playing field be ensured between traditional banks and FinTech start-ups? What are the risks? How can they be handled by supervision and regulation? We can conclude that FinTech is in the initial phase of a "revolutionary" process, and the definition of this phenomenon is broad and changing. Regulators and supervisors must influence the conditions in a way that a level playing field and risk assessment should be the same for traditional banks and FinTech companies. All of the actors have responsibility, including central banks, regulators, supervisors, incumbent banks, consumers and FinTech companies. Information is power, and several economists claim that digital is the new normal. In our paper we partly justify the first part of the sentence and we put a question mark at the end of the second part.

Journal of Economic Literature (JEL) codes: D74, G21, O33, N74

Keywords: Revolutions, Financial Institutions and Services, Technology, Diffusion Processes

\footnotetext{
* The papers in this issue contain the views of the authors which are not necessarily the same as the official views of the Magyar Nemzeti Bank.

Ádám Kerényi is a Researcher at the Institute of World Economic at the Hungarian Academy of Sciences. E-mail: kerenyi.adam@krtk.mta.hu

János Müller is an Economist, Chief Advisor of the Hungarian Banking Association, and Member of the Board of Directors of Bank of China Hungary Ltd. E-mail: mullerj1@t-online.hu

Ádám Kerényi is grateful for the grant from the National Research, Development and Innovation Office. Project no. K 128682 was funded with support from the National Research, Development and Innovation Fund and financed by the K_18 funding scheme.

The English manuscript was received on 25 June 2018.
}

DOI: http://doi.org/10.33893/FER.18.1.532 


\section{A new round of technological and digital revolution is knocking on the door}

One of the most exciting phenomenon in the world right now is the development of digitalisation. The space, emergence and social effects of this development are so rapid and so deep, that it is considered to be part of the $4^{\text {th }}$ industrial revolution. One minor part of this phenomenon is the penetration of the financial and banking sector, which is mostly referred to as the FinTech hype, because of its important role.

In order to better understand this development we briefly review the outcome of the second and third industrial revolutions and then focus on three areas - the European Union, China and Hungary - to study the present status and approach of the FinTech hype. The reason behind our research selection is that the European Union is playing a very important role not only in the development of FinTech, but also in the definition, its regulation and supervision aspects. The Chinese approach is also important since experience shows that China is facing the same or similar challenges in supervision and regulation, and on the other hand the support of FinTech development is strong. This is why we present the recent data on FinTech investment in Asia and in Europe below. The charts and figures support two important conclusions: FinTech investments are growing and reaching higher and higher levels both in Asia and in Europe (see Figure 1 and 2). It can also be seen that for the time being the European development is higher than in Asia. However, one must be careful making this comparison because the Asia line in the chart reflects the whole Asian region and we do not have equivalent data for China to compare the Chinese and European development in this respect.

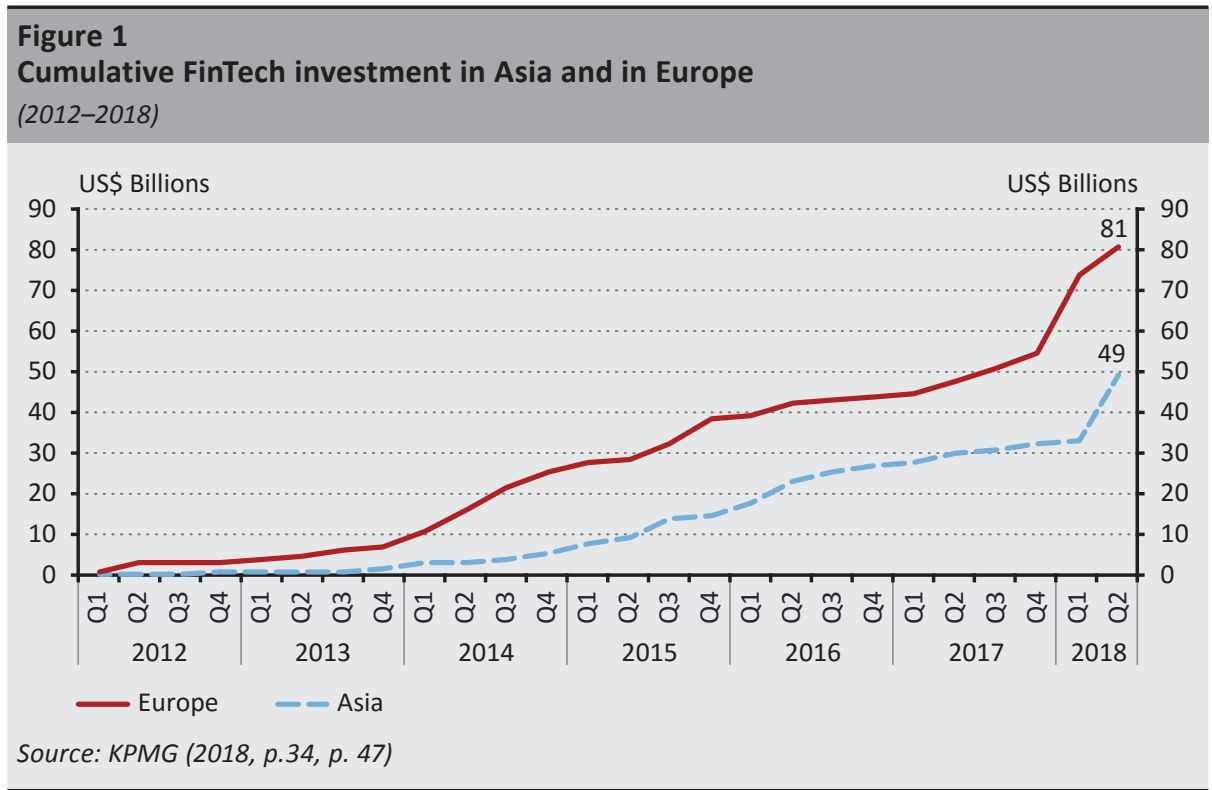




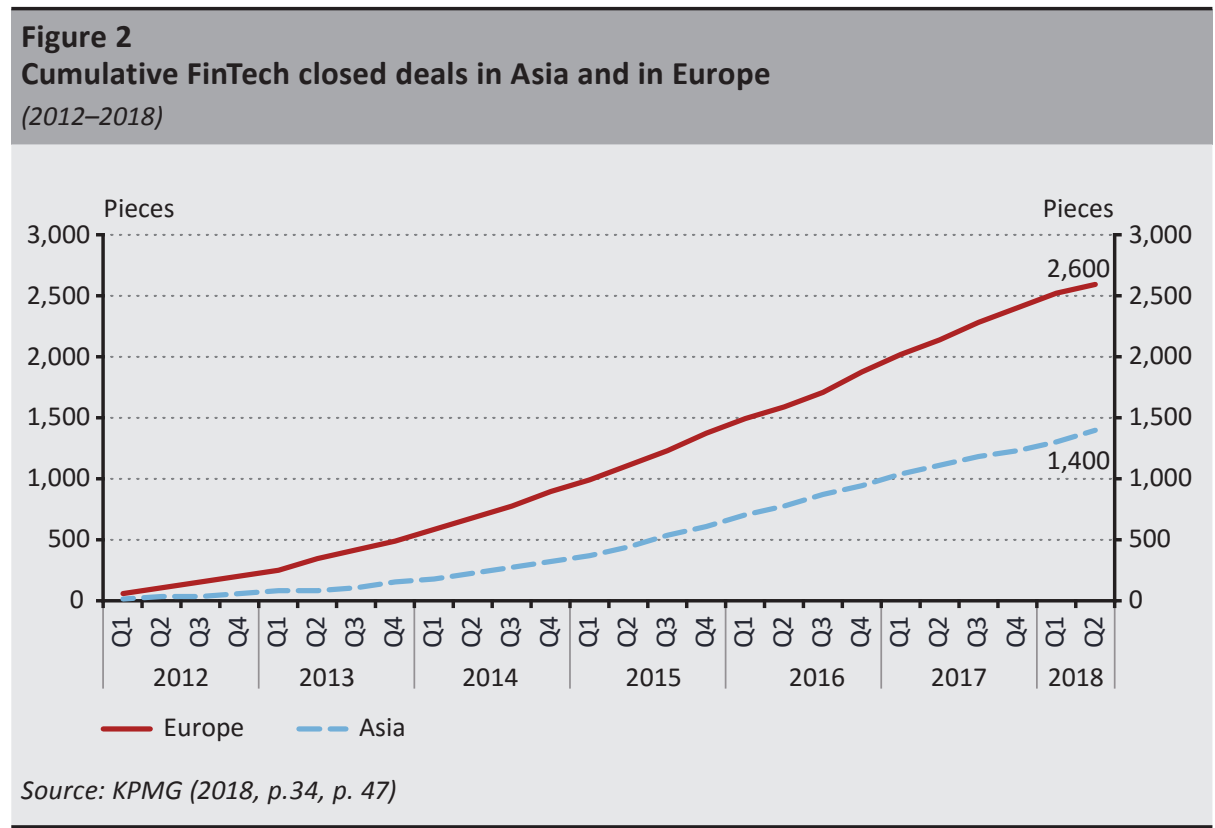

Later, we also present the Hungarian case, where for several reasons FinTech development started with some delay, but in recent years has progressed a good bit to catch up with the international level.

Since the beginning of the 21st century, we have been experiencing a digital transformation - changes associated with innovation in the field of digital technology in all aspects of society and the economy. The $4^{\text {th }}$ industrial revolution is already underway. Industry 4.0 will be an answer to the challenges lying ahead. Several economists claim that digital is the new normal. We suggest putting a question mark at the end of this statement. In this period of rapid changes, we do not know what the final shape of "the new normal" will be. "In the news, financial technology is described as 'disruptive', 'revolutionary', and armed with 'digital weapons' that will 'tear down' barriers and traditional financial institutions" (World Economic Forum 2017). This revolutionary phenomenon is inexorably occupying more and more space in our everyday lives. Naturally, these changes some revolutionary and others perceived as such - have also reached the financial and banking sector. Financial technology ('FinTech') is a broad concept. What are the main concerns of the European legislators and supervisors? First of all, the development of digital financial technology is very rapid. So rapid indeed that even the exact definition of the FinTech phenomenon is difficult. If the definition is broad and mostly an umbrella concept, then elaborating the legal framework and proper supervision is also difficult and cannot be sufficient. Supervisors are not ahead of 
the developments, but rather trailing behind them. For the time being, the principle of "same risk, same regulation" cannot be enforced.

Referring to the definition problem, examples of FinTech include digital ledger technology, robo-advice, RegTech (technologies that can be used for compliance and reporting requirements) and virtual currencies. This paper focuses on facilitating a better understanding of the FinTech phenomenon and the possible relations between traditional banks and FinTech start-ups.

Financial technology is one of the most innovative, increasingly important and potentially the most rapid change in financial services, and is revolutionising the way financial services firms operate. It is transforming debt and equity markets, payments, credit assessment, regulatory compliance, personal finance and many other facets of financial services. Although some may think that FinTech is just another "buzzword", we believe that technology creates the possibility to dramatically reshape finance as we know it. Digitisation is taking place in all areas of business and life, transforming services, and creating new ones accelerated by new FinTech companies (Deloitte 2016). The Golden Age of FinTech has come according to FinTech evangelists, but on the other hand the current hype about FinTech is not due to the allegedly revolutionary character of the technologies, but to their better visibility. Without questioning the tangible positive results, we would like to focus on the current situation of the FinTech phenomenon and its international assessment, the difficulties involved in forecasting its future prospects, and the necessity of a paradigm shift in the traditional banking system. In close relation to the latter, we review the expected evolution of the relationship between banks, FinTech companies and - last but not least - their current and future customers. Finally, the important question is whether or not there are risks related to the use of the FinTech services. If there are, how should these risks be mitigated or remedied by new regulatory and supervisory measures? One of the first questions to be answered is where do we stand in the digital technology process? Are we at the beginning or have we arrived at a balanced, calm phase of continuous development? Where is the place of the traditional banks in this process? In our opinion, the short and correct answer is: we do not know exactly. Answering this question could be helped by reviewing the lessons of the past.

\footnotetext{
${ }^{1}$ A group of researchers define the FinTech phenomenon as technology-enabled financial solutions (Arner et al. 2015). In their reading, the FinTech phenomenon is not limited to certain banking activities (e.g. financing) or business models (e.g. peer-to-peer lending, applications), but encompasses the kinds of products and services that have traditionally been provided by banks to their customers. Others (Kerényi - Molnár 2017, Kerényi - Molnár - Müller 2018, McAuley 2015, Kim et al. 2016) interpret the phenomenon more broadly, defining it as an economic industry composed of companies that use technology to make financial systems more efficient. The ECB's position is that "FinTech" is an umbrella term encompassing a wide variety of business models. In line with the ECB's responsibilities, a guide has been produced relating to technologysupported banking products and services (ECB 2017).
} 
When we investigate the possible outcome and impact of digital, Al and FinTech developments on human and social relations it is almost self-evident to compare the consequences of the third industrial revolution with the present fourth one since the latter involves the so-called digital age. Western civilisation has already witnessed three industrial revolutions, which could also be described as disruptive leaps in industrial processes resulting in significantly higher productivity. The first improved efficiency through the use of hydropower, the increasing use of steam power and the development of machine tools. The second brought electricity and mass production (assembly lines), and the third and most recent further accelerated automation using electronics and IT. The fourth industrial revolution is already underway.

We know the consequences of the first three revolutions, but we do not yet know the possible outcome of the fourth one ( $L i$ 2017).

While some areas will see fast and disruptive changes, others will change slowly and steadily, at a more "evolutionary" pace. In either case, there is no going back. In this revolution, physical objects are being seamlessly integrated into the information network. The internet is combining with intelligent machines, production systems and processes to form a sophisticated network. The real world is turning into a huge information system. This is the reason why we focus on the financial sector's role in this new revolutionary phase.

Several decades after the beginning of the third industrial revolution philosophers were still trying to summarise the relation between machines and human beings and to depict their views on the impact of the machine age on human thinking and behaviour. In our view, these questions are or could be justified in the age of digital transition and are also valid when assessing the metamorphosis of traditional banks and their clients.

Technical progress is accelerating. The empirical observation known as Moore's Law states that technical development, or certain partial processes within it, can be described by a high exponential growth path (Brock 2006, Kurzweil 2006). Nowadays, the digital transformation of financial services is a common topic in the investigation and analysis of the financial system and the banking sector. Today, a financial conference would not meet the expectations of the mainstream if it missed an item on the agenda as the word "FinTech" was not present. In many respects, the emerging opinions and findings agree: welcome the newcomer, the improving efficiency, the rising standard of consumer services, the acceleration and enforcement of competition. All of these unquestionable changes are warmly welcomed. There are, however, many aspects of the already ongoing developments and tendencies where the agreement and common understanding is not so great, and that is where important FinTech-related issues are not formulated (Taylor 2017). 
However, in addition to established financial organisations, incumbent banks are also subject to structural inertia that limits their capacity to adapt to environmental change (Buenstorf 2016). Start-ups have certain advantages over financial behemoths. The legal capital requirements for their establishment, their small size, lean culture, technological progress, and ability to attract top talents give them a competitive advantage that is inherent in their very nature. New, more convenient, customer-centred services are changing the landscape. More and more experts are thus saying that the time has come to dramatically change the incumbent banks' attitudes. The main reasons for this change are the following:

- High penetration of mobile devices,

- Growing number of digitally native customers (so-called Millennials),

- Persistent distrust towards banks, let it be real or presumed,

- Customers in general are becoming more demanding,

- Growing inequality - the need to reduce financial illiteracy, and financial inclusion stimulus,

- The popularity of FinTech hubs, labs, accelerators by local and national politicians and financial institutions.

\section{The challenge of approaching FinTech}

There is no widely accepted definition of FinTech (financial technology) in the academic economic literature. The Basel Committee of Banking Supervision (BCBS) has opted to use the Financial Stability Board's (FSB) working definition for FinTech as "technologically enabled financial innovation that could result in new business models, applications, processes, or products with an associated material effect on financial markets and institutions and the provision of financial services". This broad definition is considered pragmatic by the BCBS in the light of the current fluidity of FinTech developments. That being so, the focus of the analysis and implications of this paper is on the effects of FinTech that are particularly relevant for banks, bank supervisors and - at the end of the day - their consumers. It is also worth noting that the term FinTech is used here to describe a wide array of innovations both by incumbent banks and entrants, be they start-ups or larger technology firms.

From the above it can be seen that the definitions of both the central banks and the Basel Committee have a common feature: that FinTech (financial services) are widely interpreted and defined in a way that permits continuous change and expansion. 
The term FinTech also includes digital services and technological developmentbased business models that have already emerged in the financial market. The spread of the FinTech sector is a global phenomenon: the mass launch of new, nonbank participants and start-ups is being observed both in the developed markets (e.g. United States, United Kingdom) and in the dynamically developing markets (e.g. India, China). Service providers offering FinTech solutions have appeared in many banking fields, most frequently in payments, lending and investment advice.

As a matter of course, the permissive and broad definition outlined above has serious consequences. Since the definition does not precisely identify the content and scope of FinTech services, it creates difficulties in establishing a legislative framework to indicate the boundaries of supervisory controls, and in maintaining equal conditions for competition between traditional banks and FinTech companies.

FinTechs have an influence on how financial services are structured, provided and consumed, but have not successfully established themselves as dominant players.

Innovation is on the rise. As FinTechs have struggled to scale, banks have entered into a number of partnerships with them, and several are already bearing fruit. Banks have invested heavily for the satisfaction of their customers, and many are building compelling experiences that will meet customers' needs as never before. Furthermore, a number of institutions are effectively building new cultures, turning the page on disappointing experiences over the past decade (McKinsey 2018).

Many FinTechs came into existence with the goal of overtaking incumbents as the new dominant players in financial services, but they have shifted more towards building partnerships since they struggle with scale and customer adoption. Although FinTechs have failed to disrupt the competitive landscape, they have laid the foundation for future disruption. Some financial institutions have turned the threat of FinTechs into an opportunity (WEF 2017). Accepting the innovative importance of FinTechs, one key question is how the supervisory and regulatory institutions will approach this challenge.

As mentioned above, the FinTech phenomenon has emerged in the first phase of the fourth industrial revolution. Following the 2007-2008 international financial crisis, the primary task of traditional banks was to overcome the consequences of the crisis: they were forced to clean up their balance sheets, strengthen their capital base and cut NPL rates. They had to adapt to the strict and sometimes overly-eager regulatory conditions resulting from the crisis. They had to make significant cost reductions. As a result, traditional banks were only able to concentrate on internet services and digital developments with a delay, in recent years. Their primary focus was to recover and strengthen trust and confidence. In this situation, a market gap 
opened up for FinTech companies, as real market demand emerged. Less capital was needed to launch the operation of FinTech start-ups, and their development of financial technology in the field of payment services was fast. Furthermore, some traditional banks were open to outsourcing certain financial services ${ }^{2}$ and digital developments. Regulation and supervision of FinTech services mostly followed the rapid, changing events, consequently the regulation of third party payment (TPP) services was less strict then that of the incumbent banks.

Over the next ten years, banking will experience a higher degree of change than probably in the last 100 years. It is up to market incumbents to face this challenge. In particular, banks should rethink their business models and should look at the new wave of innovation as an opportunity to reach out to new customers, to increase efficiency, and to upgrade their business models.

However, there is a risk that the FinTech phenomenon could follow the already known pattern of shadow banking.

Speaking about the future of banking, Hatami (2015) considers five scenarios.

1. Scenario - The better bank. The digital revolution has run its course and almost all customers see digital as their main engagement mode with their bank. The incumbent big banks perceived the opportunity and reshaped their businesses to meet the new digital requirements. They restructured their IT platforms and processes, delivered new propositions internally and through partnerships, but most importantly they made the most of their key assets. They were able to retain most of their customers and retrained their people to become more digitally literate.

2. Scenario - The new bank. Incumbents were unable to survive the digital disruption. They were not able to meet the needs of their customers. These left in droves to go to the new challenger banks. These are new, full service banks built for the digital age. They provide services similar to those of the old banks, but they do it faster, cheaper and better that they ever could.

3. Scenario - The distributed bank. As the FinTech revolution progressed, large numbers of new businesses emerged to provide customers with better banking services. They did not attempt to be universal retail banks - they simply focused on providing specific products extremely well. They initially focused on payments, loans, savings products, forex, but slowly they moved into mortgages, investments, pensions and more.

\footnotetext{
${ }^{2}$ In this sense, Fintech services and products might be considered as nichetech solutions.
} 
4. Scenario - The relegated bank. In this scenario, banks become a back office service provider for front office customer-facing platforms, with banks providing the necessary licenses, access to payment networks and maintaining deposits and access to funding. There is a risk that banks and bank supervisors will have limited ability to monitor end-to-end transactions and systemic risk. The loss of the customer relationship and the dependence on these new platforms that channel financial products may have adverse consequences for risk management functions and revenue streams (revenues would need to be shared with the new intermediaries).

5. Scenario - The disintermediated bank. As customers became increasingly disenchanted with their bank, they became increasingly comfortable with going through their favourite social network or hardware provider to buy financial services. It started with payments, followed by sales finance, then investment advice, loans and savings products, until eventually all of the banks' products could be accessed by these providers. Customers felt that going through a provider they love and trust was a guarantee that they wouldn't be taken advantage of, like they felt they had by the banks (Hatami 2015, BCBS 2018).

For the traditional banks, there is also a present challenge on the human side. How do they close the digital gap in their services and also in relation to FinTech service providers?

The shortage of digital skills pits company against company in the fight to fill positions in data analytics, user experience design, artificial intelligence, cybersecurity and other areas. Half of banking institutions have a difficult or very difficult time accomplishing that task.

One new aspect of the same question is revealed in the annual banking reports of McKinsey. In 2015, they documented the potential for FinTechs and digital platform companies to erode banks' margins. However, according to their last report banks have made a lot of good news for themselves recently. One area where McKinsey is seeing radical compression is in remittances - a profit centre for banks worldwide. New firms such as Azimo, TransferWise and TransferGo have built superior technology and are able to price their services as much as 78 per cent below incumbents. As they struggle to compete, incumbents' margins are taking a pounding. Over the past two years, in markets around the world, digital entrants and new analytical firms have gained a foothold, and banks' margins are indeed falling - despite their massive cost-cutting efforts.

The digital entrants are changing too. With most retail businesses (except investing) already fully explored, at least for now, FinTechs are moving into commercial and corporate banking. McKinsey's Panorama FinTech database, which tracks over 1,000 financial start-ups, shows that one of the fastest-growing segments is 
payments solutions for large companies. The spate of alliances and acquisitions between retail banks and FinTechs has helped to solidify the notion that the land grab is over. FinTechs are also making strides in capital markets and investment banking, especially advisory - although here, the emphasis is more on enabling traditional business processes, rather than disrupting them. The threat from platform companies is real and must be addressed. McKinsey's analysts do not think, however, that it is existential for the global banking industry. The long history of banking strongly suggests that there will always be a need for financial intermediation and a profit to be made by providing capital to others, although it may take many years for the industry to return to profitability in a global economy that is undergoing profound changes. As a first step, banks can take advantage of a range of actions over the next three to five years to reclaim their rightful ownership of the customer relationship, improve productivity and industrialise their operations using digital tools. In essence, banks can deploy some of the same technologies that digital companies are using against them. These steps can lift revenues, improve capital usage, and, especially, cut costs (McKinsey 2018).

\section{The approach to FinTech in the European Union}

In the European Union, the importance of digital technology has been realised and it is considered an issue of paramount strategic, economic and social importance. The European Commission declared that the new digital technology will be a key element in the future competitive edge of the EU.

As a consequence of this development, since May 2015 the European Union has been delivering on an ambitious and comprehensive Digital Single Market Strategy which was accomplished by 2017. The SDM Strategy is built around improving access to goods, services and content, creating the appropriate legal framework for digital networks and services, and reaping the benefits of a data-based economy.

It has been estimated that the Strategy could contribute $€ 415$ billion per year to the EU economy and create hundreds of thousands of new jobs. Thus, it would be hard to understate the importance of timely implementation (European Commission 2017).

With the strategic aim of building a more competitive, innovative financial market, in March 2018 the European Commission unveiled a FinTech Action Plan focused on harnessing the opportunities presented by technology-enabled innovation in financial services (FinTech).

"Europe should become a global hub for FinTech, with EU businesses and investors able to make most of the advantages offered by the Single Market in this fast- 
moving sector. As a first major deliverable, the Commission is also putting forward new rules that will help crowdfunding platforms to grow across the EU's single market. The Action Plan envisages to enable the financial sector to make use of the rapid advances in new technologies, such as blockchain, artificial intelligence and cloud services. At the same time, it seeks to make markets safer and easier to access for new players. This will benefit consumers, investors, banks and new market players alike. In addition, the Commission is proposing a pan-European label for platforms, so that a platform licensed in one country can operate across the EU. The Action Plan is part of the Commission's efforts to build a Capital Markets Union (CMU) and a true single market for consumer financial services. It is also part of its drive to create a Digital Single Market. The Commission aims to make EU rules more future-oriented and aligned with the rapid advance of technological development" (European Commission 2018).

This strong intent of the European Union to support and motivate FinTech development is confirmed by the data below, where we can see an immense growth after 2017, when the SDM concept was accepted (see Figure 3).

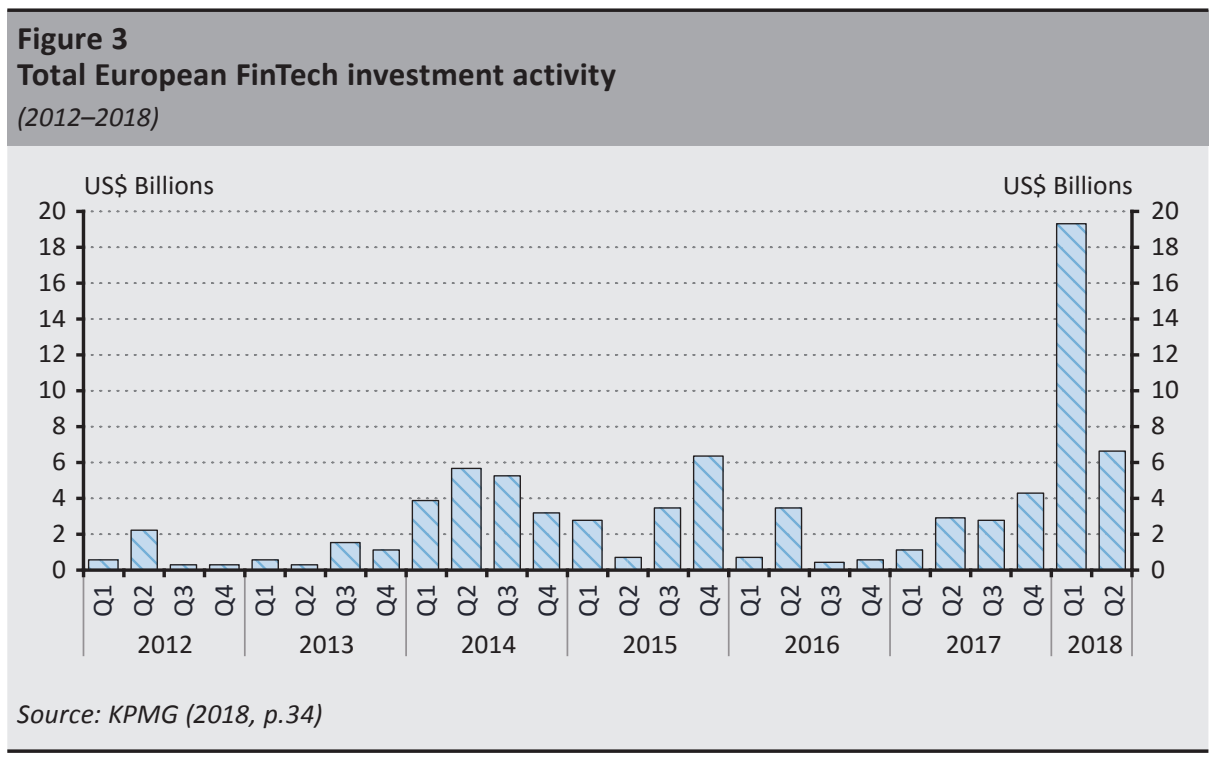

The importance of the FinTech issue in Europe is clearly reflected by the next development: the day after the EU FinTech Action plan was published, in March 2018 the European Banking Authority published its FinTech Roadmap under the title "Designing a Regulatory and Supervisory Roadmap for FinTech." 
The EBA Roadmap is an important summary of the necessary and envisaged regulatory approach related to the services provided by the incumbent banks and FinTech start-ups.

"Most of the current regulatory approaches are situated between these two extremes: "let it happen" and "regulate and restrict". They are generally based on three components:

(i) monitoring of innovation,

(i) assessment of risks vis-à-vis the public interest (micro-prudential, financial stability, consumer protection and market integrity), and

(ii) selective application of the existing rulebook, where needed adapted to capture the innovation.

In general, this pragmatic attitude revolves around a tiered regulatory structure, with differentiated regulatory requirements according to the risks for the firms, their customers, the financial sector and the economy at large. In principle, the objective is to deliver "same risk - same rules" expectations.

Let us quote another important view of this document: "Even though FinTech firms may offer some bank-like products and compete with banks for the same customers, this doesn't necessarily mean that they should be licensed, regulated and supervised as banks. We need to make a key distinction, here, between the cluster of services that represent the essence of banking, and as such should be reserved to licensed banks, and those additional services that may be offered, on a standalone basis, also by other intermediaries, in competition with regulated banks". The EBA's FinTech Roadmap describes its priorities for 2018/2019 and provides an indicative timeline for the completion of these tasks. The priorities are:

- monitoring the regulatory perimeter, including assessing current authorisation and licensing approaches to FinTech firms, and analysing regulatory sandboxes and innovation hubs in order to identify a set of best practices to enhance consistency and facilitate supervisory coordination;

- monitoring emerging trends and analysing the impact on incumbent institutions' business models and the prudential risks and opportunities arising from the use of FinTech;

- promoting best supervisory practices on assessing cybersecurity and promoting a common cyber threat testing framework;

- addressing consumer issues arising from FinTech, in particular in the areas of unclear regulatory status of FinTech firms and related disclosure to consumers, 
potential national barriers preventing FinTech firms from scaling up services to consumers across the single market, and the appropriateness of the current regulatory framework for virtual currencies;

- identifying and assessing money laundering/terrorist financing risks associated with regulated FinTech firms, technology providers and FinTech solutions (EBA 2018, Enria 2018).

In a paper "Sound Practices on the implications of FinTech developments for banks and bank supervisors", in February 2018 the Basel Committee's Financial Stability Board summarised "how technology-driven innovation in financial services, or 'FinTech', may affect the banking industry and the activities of supervisors in the near to medium term".

This extensive analysis provides an excellent understanding of financial technology developments and the presently known FinTech business models. "Against this backdrop, current observations suggest that although the banking industry has undergone multiple innovations in the past, the rapid adoption of enabling technologies and emergence of new business models pose an increasing challenge to incumbent banks in almost all the banking industry scenarios considered".

The Basel Committee summarised the ten most important possible implications of the suggested supervisory approach related to the relations of traditional banks and FinTech service providers:

1. the overarching need to ensure safety and soundness and high compliance standards without inhibiting beneficial innovation in the banking sector;

2. the key risks for banks related to FinTech developments, including strategic/ profitability risks, operational, cyber- and compliance risks;

3. the implications for banks of the use of innovative enabling technologies;

4. the implications for banks of the growing use of third parties, via outsourcing and/or partnerships;

5. cross-sectoral cooperation between bank supervisors and other relevant authorities;

6. international cooperation between bank supervisors;

7. adaptation of the supervisory skill set;

8. potential opportunities for supervisors to use innovative technologies ("suptech"); 
9. relevance of existing regulatory frameworks for new innovative business models; and

10. key features of regulatory initiatives set up to facilitate FinTech innovation.

Looking at the latest developments, it is obvious that decision-makers in the EU are aware of the importance and global competitive impact of the development of financial technology. The efforts are concentrated on strengthening the development of the European Monetary Union and the European Capital Markets Union. On the one hand, they confirm that digital applications, the availability of FinTech services should be supported, but on the other they urge an improvement of supervisory risk assessment, consumer protection and strengthening the relevant legal framework. It is strongly emphasised that a level playing field between traditional banks and FinTech (TPP) service provider should be ensured.

The lack of a precise definition most probably required the present standpoint of the European Central Bank, stating that the regulation and supervision of FinTech services should remain - for the time being - in the sphere of national competence. The next challenge is how to ensure a level playing field between the traditional banks and FinTech service providers. It is not easy to find a balanced solution. Establishing a FinTech start-up requires less capital, the acquisition of clients is cheap, and the regulation and supervision is mild or non-existent. The incumbent banks had just emerged from the consequences of the international financial crisis, with demanding budget constraints, and for this reason they had less resources available for digital developments, are subject to a strict and sometimes overregulated functional environment and face strict risk assessment criteria. On the other hand, the FinTech challenge is motivating traditional banks to catch up and to invest in financial and digital technology. The game is on: we just hope that the final outcome will be a win-win situation, offering and providing better services.

Death and taxes may have been the only certainties in the words of Benjamin Franklin two centuries ago, but today only death remains undeniable. With the rise of the digital economy, more and more economic value is derived from intangibles such as the data collected from digital platforms, social media, or the sharing economy. And because company headquarters can now be moved between countries with ease, governments are finding it ever harder to raise taxes. At the same time, public spending will likely have to increase to meet the demands of those left behind in the era of globalisation and digital technologies.

That may be about to change. One idea currently gaining traction is to tax firms offering free-to-use digital services differently, so that their intangible value receives the same tax treatment as the tangible value produced by manufacturers and traditional service providers. 
The competent EU decision-makers also realised the importance of a wellcontrolled digital (FinTech) development even from the taxation point of view. As part of building the architecture of the EU Single Digital Market, the European Commission suggested a Council Directive laying down the rules relating to the corporate taxation of a significant digital presence. According to the Commission's proposal: "The digital economy is transforming the way we interact, consume and do business. Digital companies are growing far faster than the economy at large, and this trend is set to continue." (European Commission 2018)

However, digitalisation is also putting pressure on the international taxation system, as business models change. Policy makers are currently struggling to find solutions which can ensure a fair and effective taxation as the digital transformation of the economy accelerates, and the existing corporate taxation rules are too outdated to capture this evolution.

The current corporate tax rules are built on the principle that profits should be taxed where the value is created. However, they were mainly conceived in the early 20th century for traditional "brick and mortar" businesses and define what triggers a right to tax in a country ("where to tax") and how much of corporate income is allocated to a country ("how much to tax") largely based on having a physical presence in that country and without reflecting the value created by user participation in that jurisdiction.

This proposal aims to address the issues raised by the digital economy by setting out a comprehensive solution within the existing Member States' corporate tax systems. It provides a common system for taxing digital activities in the EU which properly takes into account the features of the digital economy. First, this proposal lays down rules for establishing a taxable nexus for digital businesses operating across borders in case of a non-physical commercial presence (hereinafter: a "significant digital presence"). New indicators for such a significant digital presence are required in order to establish and protect Member States' taxing rights in relation to the new digitalised business models. Second, this proposal sets out principles for attributing profits to a digital business. These principles should better capture the value creation of digital business models which rely strongly on intangible assets. This Directive, once implemented in the Member States' national legislation, will apply to cross-border digital activities within the Union, even if the applicable double taxation treaties between Member States have not been modified accordingly. As soon as it enters into force, this EU Directive will have a positive impact on the desirable level playing field between traditional banks and FinTech start-ups. 


\section{The approach to FinTech in China}

"Competition in the FinTech space is developing at the global level. As often occurs in innovative markets, the key to success lies in a large domestic market, which allows successful companies to achieve a scale enabling them to aim for global leadership. In the long term, European FinTech players would be at a significant disadvantage vis-à-vis their US and Chinese competitors, if the European markets remain segmented along national borders, with different sets of rules and uncoordinated actions by local authorities" (Enria 2018).

In this chapter on the Chinese experience, we survey FinTech in three dimensions: the Chinese government, the People's Bank of China (the Chinese central bank) and the financial supervision authority Chinese Banking Regulation Committee $(C B R C)^{3}$, and the Chinese commercial banks.

In order to make a short summary we refer to the FinTech approach of China, which was presented by excellent high-level financial experts at the AFCA CEE Financial Summit Forum - New Chapter of Asia-Europe Financial Cooperation in Budapest, Hungary in November 2017. The FinTech sector in China has been developing rapidly and is the global leader by several measures. The country's digital payments account for almost half the global volume and online peer-to-peer (P2P) lending accounts for three quarters of the global total. China's FinTech sector is now at a critical juncture. The Chinese government's attitude towards FinTech has become progressively more complex, as risks have piled up around P2P platforms and the number of underground fund raising and financing activities have grown. The authorities remain generally supportive, despite some recent tightening measures ( $\mathrm{Hu}-\mathrm{Yin}-$ Zheng 2016, PWC China 2017).

In relation to internet finance, Premier Li Keqiang made some important statements: "We will encourage internet finance to seek a healthy development path with the backing of proper regulatory coordination and supervisory mechanisms" and "We will work to see that internet finance develops in line with regulations". The Chinese government gave players a free hand to experiment. Light-touch - or, more accurately, late-touch - regulation of digital activities and players in China has encouraged entrepreneurship and experimentation. While the response of regulators lagged behind market developments, China's internet giants were relatively free to test and commercialise products and services and to gain critical mass. For example, regulators took 11 years after Alipay introduced online money transfers in 2005 to set a cap on the value of the transfers. It was five years after Alipay introduced barcode-based payment solutions that Chinese regulators produced an official standard on management requirements (McKinsey 2017).

\footnotetext{
${ }^{3}$ In April 2018, CBIRC took over the role of CBRC, and its activity covers not only the banks but insurance companies, as well.
} 
On the side of the commercial banks let us quote the approach of some of the major Chinese financial institutions. Liu Qiang, Vice President of the Bank of China urged to take the lead in technological innovation and improve the efficiency of financial services. FinTech can improve the quality serving the real economy. The development of FinTech has enriched the content of finance and expanded the market. The combination of new technologies, capital and market can create astounding power. Banks on both sides should vigorously step up innovation and cooperation in technology and promote the transformation and upgrading of banking service efficiency. Everyone can see that technical progress is continuously pushing forward the resolving of information asymmetry, which is of great importance to financial development. FinTech has rich connotations, and will become a trend of financial development within the ceaseless technical progress.

While the growth phenomenal of traditional and non-traditional digital financial services has been fostered in recent years by technological innovation, advancement, rapidly changing consumer behaviour and adaptation to forms of finance, China's regulatory environment has also provided fertile conditions for growth. This statement is confirmed by the data below (see Figure 4).

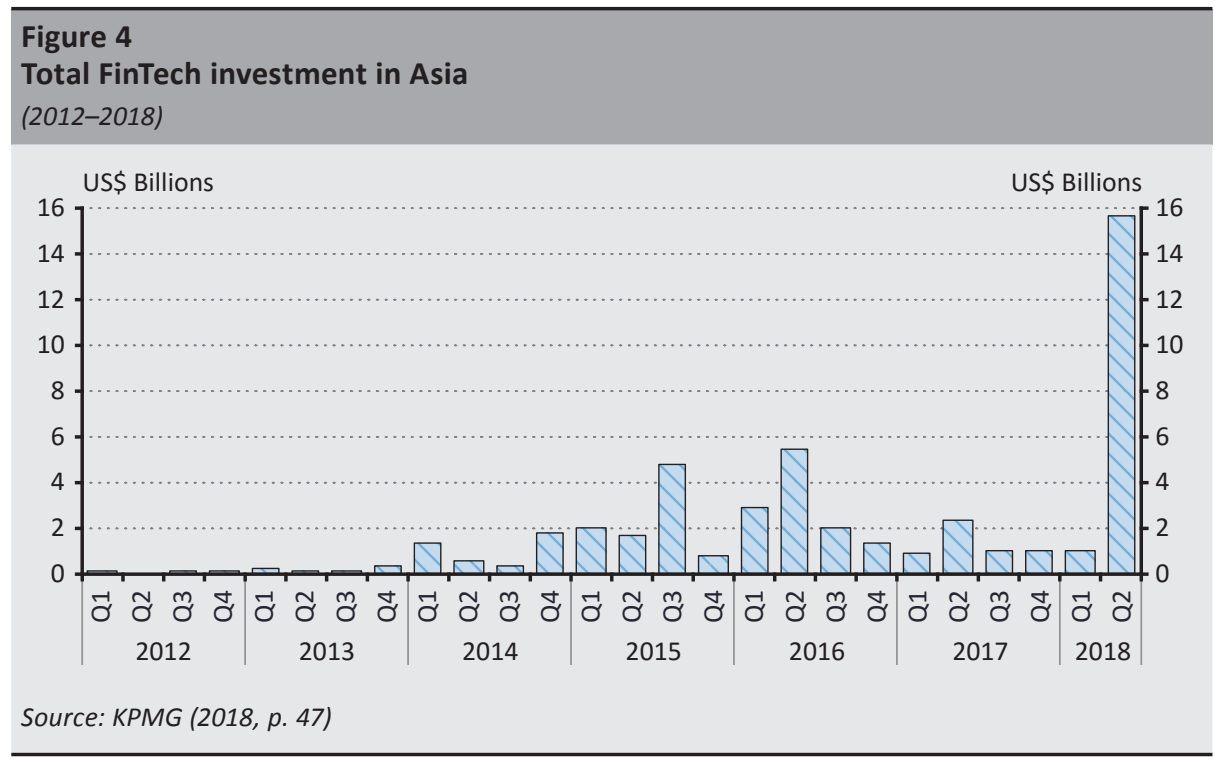


Mr Huang Yi, Executive Vice President of China Construction Bank, delivered a speech titled Financial Technology and Strategic Transformation of the Banking Industry in China. According to Yi, instead of leading to a shrinkage of the banking industry, the rapid development of China's internet finance has brought about competitive and cooperative development through two-way interaction and complementation of advantages. The breakthrough and maturity of technical fields laid a solid foundation for the technology-driven transformation of the banking industry. He also mentioned that financial technology was a more direct, powerful and effective driving force for transformation. Intuitively, the development of financial technology first broke through physical limitations effectively, and drove the integration of banking channels. Besides, the application of financial technology drove the reform of banking business modes, and gradually popularised the service modes based on scenarios and platforms. Furthermore, financial technology had enriched risk control means, making risk management more effective. He continued as follows: as financial technology had advantages, China could work to develop core technologies and set patent standards. China's commercial banks and some large internet enterprises stayed ahead in the international market in terms of financial technology practices. They should take the advantage to integrate related technologies and make these technologies their patents, and use these patent advantages to change the process of the international financial industry, to form new industrial standards and to enhance the core competitiveness of China's banking industry (Kerényi - Müller 2018).

Strengthening regulation and supervision is the focus of the CBRC, the Chinese Banking Regulatory Committee. Based on the framework, the fundamental principles governing the regulation of Digital Finance are "tolerate, encourage, guide and standardise" and the associated supervisory requirements can be summed up as "comprehensive, timely, professional and effective" (Varga 2017:134)

In 2018, at the Budapest Renminbi Initiative Conference ${ }^{4} \mathrm{Mr}$ Ren Zhe, Representative of the Peoples Bank of China, spoke about the recent development of FinTech Regulation in China. He emphasised that the definition of internet finance is broad, and internet payments, digital currencies and digital infrastructure require different approaches. Changes are needed in the regulatory and supervisory requirements and related changes in business incentives of incumbents and new players. In his opinion, "there is no unified approach to FinTech activities; improvement the ecosystem of FinTech can help mitigate some significant risks; new ideas and approaches to improve regulation efficiency should be incorporated". Since there is

${ }^{4}$ More information on this event: https://www.mnb.hu/en/pressroom/press-releases/press-releases-2018/ budapest-renminbi-initiative-2018-conference-at-the-central-bank and (Mészáros 2018). 
no unified regulatory approach on FinTech activities he emphasised the importance of self-discipline.

\section{The approach to FinTech in Hungary}

After reviewing the EU and Chinese approaches to the FinTech development, we briefly summarise the Hungarian attitudes. ${ }^{5}$

As a matter of course, the Hungarian FinTech approach is closer to that of in the European Union and rather to that within the euro area. However, there are some country-specific features. The global financial crisis also impacted the Hungarian financial sector: lending activity and profitability decreased, NPL rates rose, there was a heavy burden of FX-denominated retail loans, and internal hard budget constraints were faced within the banks. Due to the absorption of these developments, the banking sector could return to the normal development of IT and other services. Digital innovations and FinTech expansion was started in the past three to four years. Although foreign ownership is relatively high in the banking sector, at around 50 per cent, most of the FinTech developments are made at Hungarian subsidiaries and are not taken over from the parent banks. It is also a special, although not unique feature, that the Magyar Nemzeti Bank (MNB), as Hungary's central bank, has both the supervisory and regulatory competence.

Against this background, FinTech regulation is high on the MNB's agenda. When the idea of regulating FinTech first appeared to the MNB, their first step was to look for information on the best practices of other central banks around the world. The MNB considers the support of FinTech development so important that "the MNB established an Innovation Center (Multilateral Consultation Platform) to help FinTech start-ups in the initial phase, or even those already on the market, to navigate regulatory issues" (Thurzó 2017).

The MNB also prepared a targeted questionnaire to assess the attitude and proposals of market participants which are developing and offering FinTech innovations. According to this survey "banks believe that they will continue to play a central role in financial intermediation. On the other hand, the overwhelming majority of FinTech firms are in regular contact with banks or have turned to banks since their launch. This is due to the fact that in addition to financial support, banks can also provide assistance through the expertise gained during their operations. Access to banks' extensive datasets is crucial for newly established FinTech firms and banks have thorough knowledge of the detailed legal requirements pertaining

${ }^{5}$ This section is based on the Consultation Document of the Magyar Nemzeti Bank (MNB 2017, Fáykiss et al. 2018), which published the results of a market survey on FinTech innovations and their potential regulation and also based on an interview by the authors with representatives of the MNB. 
to the industry. Banks' systemic thinking can probably also provide more accurate guidance on potential operational and financial risks. Traditional banking actors mainly foresee partnership solutions with respect to FinTech innovations. Banks' motivation is based on their need to be familiar with efficient solutions and adopt them as soon as possible, and the flexibility observed in the attitude of FinTech firms and their ability to make decisions quickly may facilitate technological progress. One major element of cooperation is the provision of a business model which is sustainable over the longer term. Banks believe that cooperation and the development of incubation programmes can facilitate long-term thinking, and as a result of that, innovations can become part of the traditional banking system" (MNB 2017).

The MNB's Innovation Hub (which was recently founded) helps to identify actually arising legal obstacles and to improve feasibility of innovative ideas (Fáykiss et al. 2018). The online platform provides a connection between the regulatory and supervisory authority and the innovative domestic institutions (FinTech firms, banks, insurers, etc.), and supports the awareness of international best practices.

- Information repository

- Communication hub

- Regulatory support platform

- International cooperation platform

"However, some uncertainty also surrounds the Regulatory Sandbox, as 65 per cent of the institutions have not decided whether they wish to participate, whereas 29 per cent of the respondents would be willing and able to launch a testing phase with an innovative product or service even within a short period of time. Most FinTech firms already cooperate with traditional banking actors. FinTech firms typically do not feel rejected by banks. The market consultation confirmed that there are different types of cooperation. Over one-third of the Hungarian companies in the MNB's sample indicated that they are in a partnership with a bank, i.e. they are participating in a bank's incubation program or acting as suppliers to a bank with an agency agreement. Banks obtain FinTechs' know-how through acquisition fairly rarely. Openness on the part of the FinTech firms will typically continue, as half of the sample plan further cooperation. Complete rejection of cooperation was only indicated by three companies altogether" (MNB 2017).

Finally, it is also of great interest to see how the traditional banks consider the development of FinTech in Hungary. The Chairman of Hungarian Banking Association summarised his views on the digital and FinTech challenges as follows: "Digitalisation is a tremendous challenge and pressure for renewal in the banking 
sector. Many people who are 20 or 30 years old today will not visit a branch office, and instead conduct all of their transactions on their mobile phones. Client attitudes and behaviour will change, the importance of branches will decrease and the importance of technology will increase. For many banks it's a real danger that their role will be taken over by new actors, for instance payment service providers. This development is seen by regulators all over the world, and if these actors want to have lending activities and will observe and comply with the relevant rules, they will have to meet the same capital requirements as traditional banks, then the banks will win and defeat them in competition. The danger is there, but banks will learn how to apply the new technologies rather than to let new actors take away their bread. Banks are ready for the serious integration of FinTech companies." (Patai 2018). For the time being it is a positive attitude even for the clients that the incumbent Hungarian banks do not have a hostile attitude towards FinTech start-ups.

\section{Summary and Conclusion}

Since the beginning of the 21st century, we have been experiencing a digital transformation - changes associated with innovation in the field of digital technology in all aspects of society and the economy. The fourth industrial revolution is already underway. Financial Technology represents one of the most innovative, increasingly important and potentially the most rapid change in financial services revolutionising the way financial services firms operate and transforming debt and equity markets, payments, credit assessment, regulatory compliance, personal finance and many other aspects of financial services. For a better understanding of this process, we have briefly compared the lessons from the previous three industrial revolutions. We can see similarities, as revolutions have a sudden start and mostly end up with positive changes and transformational powers, but they also have disruptive effects. In the initial phase it is difficult to predict the outcome, to foresee what will be a lasting positive effect and to assess the potential risks involved and their management.

In our day and age, one of the greatest challenges for the banking sector, for the regulators and for supervisors is the digital transformation of financial services. In this context, the future of traditional financial intermediation and the relationship between incumbent banks and FinTech start-up companies is a relevant question. These developments and the new actors on the market raise the question of potential risks, thus how regulation and supervision should be changed, and whether fair competition and a level playing field can be ensured and maintained.

In investigating the FinTech phenomenon, the first task is to find the exact definition. It is clear that there is no widely accepted definition of financial technology, not because regulators are ignorant or unknowledgeable, but rather because the 
development is so rapid that supervisors and central banks are forced to follow the events. The inefficient status of the definition is common in all of the territories we examined. The most commonly used definition is the Financial Stability Board's working definition of FinTech as "technologically enabled financial innovation that could result in new business models, applications, processes, or products with an associated material effect on financial markets and institutions and the provision of financial services". This broad, "pragmatic" definition is considered as the basis of regulation.

The permissive and broad definition has consequences. Since the definition does not make it possible to precisely identify the content and scope of FinTech services, it creates difficulties in establishing the legislative framework to indicate the boundaries of supervisory controls, and in establishing equal conditions of competition between traditional banks and FinTech companies. If strict regulatory requirements are imposed on banking actors, FinTech firms would enjoy an unfair competitive advantage, and the lack of detailed rules also poses risks to stakeholders. If an immature solution reaches the market too soon, it may cause unexpected losses to both consumers and lenders. An excessively lenient regulatory approach may push financial intermediation into a segment where regulatory authorities only have limited influence.

After the chronological and global review, we focused our examination on three geographic areas: the European Union, China and Hungary. In our view the first two support our endeavour to identify the direction of the global financial digital development, to find similarities and differences in the approaches and ultimately to explore where Hungary stands in this process.

In the European Union, the importance of digital technology has been realised and it is considered an issue of paramount strategic, economic and social importance. The European Commission declared that the new digital technology will be a key element in the future competitive edge of the EU. This is why the European Union has been delivering on an ambitious and comprehensive Digital Single Market Strategy, which was shortly followed by FinTech Action Plan in 2018. In order to strengthen the accomplishment of these targets, the European Banking Authority published its FinTech Roadmap under the title: "Designing a Regulatory and Supervisory Roadmap for FinTech". The EBA Roadmap is an important summary of the necessary and envisaged regulatory approach related to the services provided by incumbent banks and FinTech start-ups.

The definition of FinTech used in the EU is broad, but regulators are struggling to mitigate risks and ensure fair competition. They follow a pragmatic attitude that revolves around a tiered regulatory structure, with differentiated regulatory 
requirements according to the risks for the firms, their customers, the financial sector and the economy at large. In principle, the objective is to deliver "same risk - same rules" expectations.

The lack of an exact definition most probably required the present standpoint of the European Central Bank (ECB), which has stated that the regulation and supervision of FinTech services should remain - for the time being - in the sphere of national competence. This statement in itself shows how difficult it would be at present to centrally regulate this process and activity. The next challenge is how to ensure a level playing field between traditional banks and FinTech service providers. It is not easy to find a balanced solution. Another delicate problem is the question of taxation. As part of building the architecture of the EU Single Digital Market, the European Commission proposed a Council Directive laying down the rules relating to the corporate taxation of a significant digital presence.

The next chapter of this study is an overview of the FinTech approach in China, where the FinTech sector has been developing rapidly and is the world leader by several measures. The country's digital payments account for almost half the global volume and online peer-to-peer (P2P) lending accounts for three quarters of the global total. However China's FinTech sector is now at a critical juncture. Some years ago, problems emerged when risks piled up around P2P platforms and the number of underground fundraising and financing activities multiplied. This served as a lesson and a warning for the regulators and supervisors, and their changing attitude is moral and instructive to many other countries. Otherwise, the Chinese approach is similar in many ways to that of the EU. For example, in the view of the Peoples Bank of China there is no unified approach to FinTech activities; improving the ecosystem for FinTech can help mitigate some significant risks; new ideas and approaches to improve regulation efficiency should be incorporated. In this situation a self-discipline requirement is also inevitable.

After reviewing the EU and Chinese FinTech approaches it is refreshing to present the Hungarian case. One can state that Hungary is not lagging behind even if its regulators and traditional banks face similar tasks as in the EU or China. We relied on the latest surveys of the Hungarian Central Bank. There is a promising process to integrate innovative products and solutions in banking operations.

Banks in Hungary are confident that they will continue to play a central role in financial intermediation. On the other hand, the overwhelming majority of FinTech firms are in regular contact with banks or have turned to banks since their launch. According to the result of the MNB survey, the active involvement of regulators and supervisory authorities is necessary to promote competition or cooperation between various market participants and new entrants. 
According to the Hungarian banking community, digitalisation is a tremendous challenge and pressure for renewal for the banking sector. Many of those who are 20 or 30 years old today will not visit a branch offices, but rather conduct all their transactions on their mobile phones. Client attitudes and behaviour will change, the importance of branches will decrease, and the importance of technology will increase. One general, real risk is that the role of some banks will be taken over by new actors, for instance payment service providers.

The title of this study was inspired by a famous book by Aldous Huxley (18941963), "Brave New World", published in 1931. Huxley, while ironically criticising the consumer society, manipulated and ruled by the world of machines, tried to forecast the future of mankind. A great part of his vision mixed with science fiction and scientific elements became reality in the following decades. One may even say that a better a brave new world was built up on the basis by the world of machines.

We are not evangelists, we are not trying to predict the final outcome of the digital financial transformation, but we do believe that this development might present mankind with positive changes. However banking and financial services are one of the most important elements of the economy and of society as a whole, and therefore we must carefully scrutinise FinTech developments. It must be seen if there are risks, how these can be controlled or mitigated.

Almost one hundred years after the beginning of the third industrial revolution, philosophers were still trying to summarise the relation between machines and human beings and to present their view of the impact of the machine age on human thinking and behaviour. In our view, these questions are or could be justified in the age of digital transition and are also valid when assessing the metamorphosis of traditional banks and their clients. At the end of the day, FinTech should serve a better life for human beings.

At this point, we sum up the major conclusions of our analysis. We can conclude that FinTech is in the initial phase of a rapidly changing and expanding global "revolutionary" development process. It is therefore in the era of disruptive changes, and the time of a calm, predictable development has not arrived yet. Although investments in FinTech have been expanding very rapidly in financial markets, their potential impact on banks and financial institutions is still far from clear. The tension between stability and competition underlies the entire debate over FinTech and how to regulate it, be it in the European Union, China or Hungary.

We can state at this point in the development process that financial technology is proceeding rapidly, and the definition of this subject is broad and changing. Because of the fast changes regulators and supervisors are not ahead but rather trying to catch up with this process. The broad and mostly permissive definition 
makes it more difficult to ensure equal competitive conditions and a level playing field between traditional banks and FinTech start-ups, and in practical terms this means that banking regulation and supervision are more strict.

The relationship between traditional banks and Fintech start-ups is developing and changing. Several attributes characterise the possible relationship between traditional banks and FinTech companies, such as fatal attraction or dangerous liaisons. The acceptance is also different: evangelists loudly welcome the developments, while sceptics are cautious.

Whatever the outcome of the FinTech development is, the analysis above shows that we are witnessing a very fast and inevitable process, which has global and competitive implications. This paper was also focused on the wish for a better understanding of the FinTech phenomenon and the possible relationship between traditional banks and FinTech start-ups. In our view banks and FinTech firms have more common business interests than issues that divide them.

Even in the background of this digital development there are human beings, and therefore one great question is how will the society be transformed during and after the digital revolution. Retrospection sometimes helps to understand the future of present developments. Let us support our idea with the following quotation from Karl Jaspers: "The everyday complexity of the world flooded by technology forces us to reign over the world in the environment (Umwelt) that is accessible for us. Relationship to things has changed; things moved away from us, became indifferent while taking the form of unchangeable factors; technology has cut off man from the immediate presence. The new task that needs to be accomplished is that with the aid of technical creations to re-find the direct existence for all things that make up the world. The new conditions created by the development of technical possibilities should be applied in the service of man" (Jaspers 1946).

Several economists have claimed that digital is the new normal. We suggest putting a question mark at the end of this statement. In this time of rapid changes we do not know what the final shape of "the new normal" will be. "In the news, financial technology is described as 'disruptive', 'revolutionary', and armed with 'digital weapons' that will 'tear down' barriers and traditional financial institutions" (World Economic Forum 2017).

One may ask whether society and the economy are prepared or ready to face these challenges. The answer is no. All of the actors have responsibility: the central banks, regulators, supervisors, incumbent banks, consumers and FinTech companies alike. All of the regulators and supervisors are following the stormy development, applying a pragmatic definition, trying to ensure a level playing field for the main actors; incumbent banks and FinTech companies are testing each other and the 
market, while working on more and more new FinTech applications. Consumers are happy about quicker, cheaper financial services, but they require safety from their traditional banks, and mostly have trust and confidence in the incumbent banks.

Most of the central banks and regulators warn about potential risks. Risk assessment is not easy in this rapidly changing world. Sometimes "machines" collect and evaluate the data for risk assessment. Earlier we mentioned that information is power. Regulators must strictly ensure that the digital data holdings of FinTechs and financial service providers are not misused against the customers.

The rapid development of FinTech services have also been supported by a grace period. By this we mean that the global financial sector has now enjoyed almost a decade of peaceful development. The real measure of the possible risks will emerge when a new recession or crisis period arrives. The financial sector should be prepared.

\section{References}

Arner, D.W. - Barberis, J. - Buckley, R.P. (2015): The Evolution of FinTech: A New Post-Crisis Paradigm? in University of Hong Kong Faculty of Law Research Paper No. 2015/047, October.

Authority of the House of Lords (2018): Al in the UK: ready, willing and able? HL Paper 100. https://publications.parliament.uk/pa/ld201719/ldselect/ldai/100/100.pdf. Downloaded: 24 May 2018.

Basel Committee on Banking Supervision (BCBS) (2018): Sound Practices. Implications of FinTech developments for banks and bank supervisors. https://www.bis.org/bcbs/publ/ d431.pdf. Downloaded: 24 May 2018.

Buenstorf, G. (2016): Schumpeterian incumbents and industry evolution. Journal of Evolutionary Economics, 26(4): 823-836. https://doi.org/10.1007/s00191-015-0423-7

Brock, D.C. (ed.) (2006): Understanding Moore's Law: Four Decades of Innovation. Philadelphia: Chemical Heritage Press.

Deloitte (2016): FinTech in the CEE region. https://www2.deloitte.com/ce/en/pages/aboutdeloitte/articles/fintech-cee-region.html. Downloaded: 24 May 2018.

ECB (2017): Guide to assessments of fintech credit institution licence applications. Banking Supervision, European Central Bank. https://www.bankingsupervision.europa.eu/ legalframework/publiccons/pdf/licensing_and_fintech/ssm.guide_on_assessment_for_ licensing_of_fintech_credit_insts_draft.en.pdf. Downloaded: 24 May 2018. 
European Banking Authority (EBA) (2018): The EBA's FinTech Roadmap. Conclusions from the consultation on the EBA's approach to financial technology (FinTech). http://www. eba.europa.eu/documents/10180/1919160/EBA+FinTech+Roadmap.pdf. Downloaded: 24 May 2018.

Enria, A. (2018): Designing a Regulatory and Supervisory Roadmap for FinTech.

European Commission (2017): The Digital Single Market State of Play. Prepared for the Digital Summit Tallinn, 29 September 2017 https://www.eu2017.ee/sites/default/files/2017-09/ EC\%20for\%20TDS_The\%20Digital\%20Single\%20Market\%20Strategy.pdf. Downloaded: 24 May 2018.

European Commission (2018): FinTech: Commission takes action for a more competitive and innovative financial market. Press release. Brussels, 8 March 2018. http://europa. eu/rapid/press-release_IP-18-1403_en.htm

Fáykiss, P. - Papp, D. - Sajtos, P. - Tőrös, Á. (2018): Regulatory Tools to Encourage FinTech Innovations: The Innovation Hub and Regulatory Sandbox in International Practice. Financial and Economic Review, 17(2): 43-67. http://doi.org/10.25201/FER.17.2.4367

Hatami, A. (2015): The future of banking: four scenarios. http://banknxt.com/53478/futurebanking-scenarios/. Downloaded: 24 May 2018.

Hu, B. - Yin, Z. - Zheng, L. (2016): Development of China's Financial Supervision and Regulation. Palgrave McMillan.

Jaspers, K. (1946): La Nef. Occidental Press, Washington D.C., 1967.

Kerényi, Á. - Müller, J. (2018): Experts' Comments from the Host Country. AFCA BOOKLET.

Kerényi, Á. - Molnár, J. (2017): The Impact of the Fintech Phenomenon - Radical Change Occurs in the Financial Sector? Financial and Economic Review, 16(3): 32-50. http://doi. org/10.25201/FER.16.3.3250

Kerényi, Á. - Molnár, J. - Müller, J. (2018): Bank and fintechs: Healthy cooperation or dangerous liaisons? Economy and Finance, 2018(1): 86-97. http://www.bankszovetseg. hu/Public/gep/2018/ENG/086-097ig\%20kerenyi-molnar-muller.pdf. Downloaded: 24 May 2018.

Kim, Y. - Choi, J. - Park, Y.-J. - Yeon, J. (2016): The Adoption of Mobile Payment Services for "FinTech". International Journal of Applied Engineering Research, 11(2): 1058-1061.

KPMG (2018): The Pulse of Fintech H1 2018: The Pulse of Fintech 2018 Biannual global analysis of investment in fintech. https://assets.kpmg.com/content/dam/kpmg/xx/ pdf/2018/07/h1-2018-pulse-of-fintech.pdf. Downloaded: 24 December 2018. 
Kurzweil, R. (2006): The Singularity Is Near: When Humans Transcend Biology. New York: Penguin Books.

Li, X. (2017): China's Digital Economy and Made in China 2025. Institute of Industrial Economics, CASS.

McAuley, D. (2015): What is FinTech. Wharton FinTech. https://medium.com/whartonFinTech/what-is-FinTech-77d3d5a3e677. Downloaded: 10 September 2018.

McKinsey (2017): China's digital economy a leading global force. Discussion Paper.

McKinsey (2018): The Phoenix Rises: Remaking the Bank for An Ecosystem World. McKinsey Global Banking. Annual Review 2017.

Mészáros, T. (2018): Report on the Budapest Renminbi Initiative 2018 Conference. Financial and Economic Review, 17(2): 156-160. http://english.hitelintezetiszemle.hu/letoltes/fer17-2-cr1-meszaros.pdf.

MNB (2017): Innovation and stability overview of FinTech in Hungary. Consultation document.

Patai, M. (2018): Interview. In Aréna. Inforádió. https://infostart.hu/video/oTiVHDCltzw. Downloaded: 24 May 2018.

PWC China (2017): Global FinTech Survey China Summary 2017. https://www.pwccn.com/ en/industries/financial-services/publications/global-fintech-survey-china-summary-2017. html. Downloaded: 24 May 2018.

Taylor, C. (2017): The Golden Age of FinTech is Here, According to Fintech Evangelist Ron Suber. http://finteknews.com/golden-age-FinTech-according-FinTech-evangelist-ron-suber/.

Thurzó, Á. (2017): Példátlan húzásra készül az MNB, egy csapásra egy új világba repítik Magyarországot. In Portfolio.hu https://www.portfolio.hu/vallalatok/it/peldatlanhuzasra-keszul-az-mnb-egy-csapasra-egy-uj-vilagba-repitik-magyarorszagot.265025.html. Downloaded: 24 December 2018.

Varga, B. (2017): Current Challenges Facing Chinese Financial Supervision and Methods of Handling these Challenges. Financial and Economic Review, 16(Special Issue): 126-139. http://english.hitelintezetiszemle.hu/letoltes/bence-varga.pdf

World Economic Forum (WEF) (2017): Beyond FinTech: A Pragmatic Assessment of Disruptive Potential In Financial Services. http://www3.weforum.org/docs/Beyond_FinTech___A_ Pragmatic_Assessment_of_Disruptive_Potential_in_Financial_Services.pdf. Downloaded: 24 May 2018. 